\title{
Analysis of the Implementation of the Basic Training Tiered Kindergarten Educators in Sidoarjo
}

\author{
Siti Fatimah Soenaryo \\ University of Muhammadiyah \\ Malang \\ fatimahsoenaryo@yahoo.co.id
}

\author{
Beti Istanti Suwandayani \\ University of Muhammadiyah \\ Malang \\ beti.istanti@gmail.com
}

\author{
Reni Dwi Susanti \\ University of Muhammadiyah \\ Malang \\ renidwi@umm.ac.id
}

\begin{abstract}
This research aims to analyze the implementation of the basic training program of tiered, factor endowments, and the basic training program of an inhibitor factor kindergarten educators in Sidoarjo, East Java. This research uses qualitative descriptive approach. Data collection techniques are used in the form of observation, interview and documentation. This research use three stages of data analysis, namely data reduction, the presentation of data, and the withdrawal of the conclusion. Test the validity of the data using triangular data collection. The results of this research show that: basic training program implementation through several stages, namely preparation, monitoring, determination, success criteria and reporting, factor endowments program implementation training base is the motivation participants, the availability of funds and facilities while factors restricting where and commitment of participants basic tiered training kindergarten educators in Sidoarjo.
\end{abstract}

Keywords: Basic Training Program Is Tiered, kindergarten educators

\section{INTRODUCTION}

Early childhood education (ECE) has the role of strategy in the development of human resources. The role of educators and educational personnel in dealing with the institution of early chilhood education human resources is responsible for the implementation of the service quality of ECE. Early childhood education preparing children to be ready in the following primary education. Therefore the implementation of education need to be well prepared through the implementation of quality improvement training for educators, early childhood education (ECE). Educators are ECE and doing their job as teacher in the children's Nursery (TPA), group play (KB), kindergartens, a type of ECE Units (SPS). So expect ECE and educators have a competence standard of education, namely pedagogic competence, personality, social and professional.

Education will be an early age is a period of the Foundress or foundation for children's growth and development during the next. The time of happy children are the basis for success in the future. To achieve growth and development reached its full potential, then needed a conducive and efforts situation in accordance with the needs of the child

The golden period during the period of child development occurs only one time in a human life. The stimulus from the environment are indispensable in developing children's intelligence potential. Early education efforts as a form of psychosocial stimulation should be performed exactly according to your needs and stages of child development. So that these efforts can be expected to contribute significantly in increasing human quality of Indonesia.

The potential for development in the age of gold (the golden age) requires a balanced nutritional intake, health protection, compassionate care, and educational stimulation that correspond to the stage of development is done since in the womb until the age of 8 years with the gradual way, complete, consistent and repeatable so it has power change that will benefit children. The increase of the age the child needs more lengkah education stimulus for increased growth and development aspects. Accordingly the stimulation of education given at home (home base) and outdoors (center base) is useful for obtaining optimal results.

Process of the implementation of the early childhood education (ECE) consists of several components that mutually influence one another. Component on the process of the implementation of the early childhood education (ECE) in order to achieve the objectives that had been planned. Kindergarten educator is one of the components that have an active role in the implementation of the early childhood education, this is because education serves as the implementing teaching and learning activities. Law No. 20 of 2003 National education system States that the kindergarten teacher should have the competence of educators or teachers of early childhood education institutions has at least four academic diploma (D-IV) or Bachelor's degree (S-1) the field of early childhood education, and the teaching profession has an kindergarten or at least have gotten training in early childhood education.

Public policy is what is revealed and done or not done by the ruler that can be defined in the legislation or in the 
peruaturan police statement in the form of speech and discourse of political officials and expressed Government officials who quickly followed up with the program and Government's actions [1]. Policies for early childhood education services is a strategic step for preparing a superior human resources and competitive in the future.

One of the characteristics of the era of globalization is the occurrence of global competition, including competition in obtaining peluar work. In these conditions, only the human resources that have the capability of Excel that can seize the opportunity. Therefore, health care services, programs and early childhood education is a priority and urgent need to do in order to prepare the Foundation of a child into a human superior.

According to the Director General PTK PAUDNI [2] ,qualification of kindergarten educators academic S1/D4 is $15,72 \%$ does that mean kindergarten educator qualifications in Indonesia is still largely set in secondary education, education or under D-2, i.e. $60.4 \%$. This data shows that the kindergarten teachers running the task exceeded his authority and was not in accordance with the number 16-year 2007 Permendiknas on standard academic qualification and competence of teachers as well as number 58-year 2009 Permendiknas about kindergarten and educational standards.

Professionalism of educators is the ability of an educator as a teacher in the discharge of duty. The implementation begins with planning to evaluating learning. One of the constraints in an attempt to achieve the vision and mission of the school, namely educators qualification who are not of the level of the field. So to overcome the need for training and education activities (training and education) to increase the professionalism of educators.

Training is a form of employee development that ultimately have an impact on improving the performance of employees. The function of training is very important to improve the quality of educators in the schools. According to Simamora [3] purpose carried out a training and development, among others, to improve performance, help solve operational problems, and prepare employees for promotion and meet personal needs.

Directorate of construction of educators and educational personnel early childhood Education [4] program is Tiered the Ministry of education and culture (Basic Training, Advanced Training and Advanced Training). The basic training of kindergarten educators is part of kindergarten and tiered training mandated by the Directorate of construction of educators and educational personnel early childhood Education, non formal, and informal (Dit.PPTK PAUDNI). The base implementation of the training kindergarten educators is Permendiknas number 16 years 2007 [5] about the standard of kindergarten and Permendiknas No. 58 year 2009 [6] about the competence and qualifications of academic kindergarten educators.

HIMPAUDI is a one of the provider who got the recommendation from the Directorate of training and education to organise P2TK Tiered Training i.e. basic level, Advanced Training and Advanced Training in order to improve the competence of kindergarten educators teaching.

\section{METHOD}

The research approach used is qualitative descriptive. Descriptive research is essentially attempting to descriptive in essence attempting to describe, interpret, analyze and record the conditions is taking place. The research was done starting in February until April of 2018.

The subject in this research is to the field of non formal education (KaBid PNF), the head of the Organizing Committee, organizer of the kindergarten teaching training base, as well as kindergarten educator Training that follows the kindergarten Basic Education Educator, as well as kindergarten as following the Basic Training of the 2018. Data collection techniques in the study of using observation, interview and documentation. While the techniques of data analysis through data reduction, the presentation of the data and the withdrawal of the conclusion

\section{RESULT}

Now many kindergarten teachers who have yet to understand what method is right for applied to early childhood, for it is necessary the presence of a container to accommodate aspirasinya and place a consultation related constraints faced by kindergarten teacher. HIMPAUDI in Sidoarjo is a container that hold various Affairs and activities kindergarten in the region on Sidoarjo. One of its activities is inaugural tiered basic training kindergarten teacher in an effort improve the competence and professionalism of teaching.

Tiered training was implemented by HIMPAUDI Sidoarjo is a basic level of training was devoted to preparing educators as caregiver with minimal competence. Advanced level of training is intended to prepare competent educators as teachers escort. The stages of the implementation of the basic training of kindergarten program on 2016 in Sidoarjo is a: a) prepare, b) implementation, c) monitoring, d) determination of success criteria, d) reporting. While the size and training of the basic policy objectives is one of the efforts to improve the competence of kindergarten educators.

Determining the schedule of implementation this training was organized by the HIMPAUDI SIDOARJO after the preparation of the training finished. As for the preparations done i.e. determine training, officials of the location or place to be used for training activities and technical implementation. Schedule the implementation of basic training was determined by a tiered HIMPAUDI Sidoarjo based on the mutual agreement of the implementation schedule of the related training, and training comitte will socialize schedules the execution of 
basic training on tiered participants of training namely kindergarten educators.

The requirement that must be met by the participants of the training consists of the General conditions and the special conditions, General conditions i.e. participants should follow healthy physical and spiritual. Then followed diklast willing to start from the beginning to the end of the activity. Whereas special conditions in basic training: a minimum age of 17 years old or high school educated or equal work, experienced for at least 1 year (shown with active teaching SK) and preferred never to follow kindergarten training.

Basic training tiered was implemented by Himpaudi Sidoarjo aims to enhance the professionalism of kindergarten teachers and help grow help grow fhibiscus learners in early childhood opimal. In addition to improving the quality of teaching kindergarten teacher., his activity also aims to recommend a kindergarten who has not qualified o follow the kindergarten Undergraduate qualification. As for the principal activities performed by a Himpaudi in this training activity is 1) improve the professionalism of the kindergarten teachers, 2) encourage educators and can continue to study in higher education, 3) convey information or assistance like scholarship, if there is a related announcement, 4) push in order to satisfy the welfare funds through improved kindergarten educator incentive fund they follow on competence, certification and other related consultation activities as well as the kindergarten.

Home Basic training for kindergarten educators also assist education service recipient selects the candidate in Sidoarjo incentive becomes easier. The materials presented by the interviewees is a materials-based experience and the needs of educators in kindergarten and carry out instruction

Human resources play a role in the implementation of basic training was the most important of which is the existence of policies which govern competencies, standards and qualifications of educators who later followed up with the old implementation of basic training for kindergarten educator. In addition the implementation of basic training was supported also by the availability of funds from APBD.

The characteristics of the implementing agency, the parties involved in the implementation of the basic training program of kindergarten educator. Based on the results of interviews indicate that the parties involved in the the implementation of the basic training program of educators is policy of Dit. PPTK PAUDNI, education service Agencies Sidoarjo, Committee organizers, participants and resource persons in attendance of some components such as BPKB, SKB, HIMPAUDI and akademy.

The attitude of the execution of the program implementation tends to receive basic training. This is reflected in the attitude of the speaker, organizers, and participants who have been carrying out their respective roles. In addition, the implementation of the basic training program can be established in accordance with a predetermined schedule, When implementing the activities of the Agency rejects the policy of increased competence and qualifications kindergarten educators, then the basic training programs implementation of kindergarten educator will never gets done properly.

In terms of communication in the activities reflected in the excellent socializing, one form of communication that is created between the parties involved in the implementation of the basic training program of kindergarten educators in Office Of Education Sidoarjo. The social environment is demanding kindergarten educator to do a quality learning activities in each of these institutions. Then dit. PPTK PAUDNI through the Department of education to implement the basic training program of Sidoarjo as a form of facilities to increased competence and qualifications of kindergarten educators. So that the implementation of basic training program supported by the needs of the environment in this case quality kindergarten educators. During the implementation of the basic training program of kindergarten educators in Sidoarjo not encountered a very serious problem in terms of economic, social and even political.

Supporting factors the implementation of this basic training programme is awareness the kindergarten educators to following the basic training, the availability of funds and resources and the availability of facilities conducting basic training in education service Sidoarjo. Kindergarten educators motivated to follow basic training in order to be able to educate in accordance with Permendikas criteria and psychological for learners.

While the factors restricting implementation of project this is a problem spot for the implementation of such activities and of the difficulty of prosecuting participants are committed to following the basic training for 7 days because participants have to leave the institution of the place of work and family.

\section{CONCLUSION}

The stages are done in the basic training programme implementation of kondergarten educator on 2016 in Sidoarjo is 1) prepare, 2) implementation, 3) monitoring, 4) determination of success criteria, 5) reporting. Some of the things that affect the implementation of the basic training program in Sidoarjo in kindergarten educators such as: the size and purpose of the policy, the implementing agent characteristics, the attitude of the executor, the source of resources, communication and the environment.

Basic training factors implementation that supporting this tiered is the high participants motivation to follow basic training, the availability of a resource that is capable of delivering very well. While the factors restricting implementation of basic training programs of kindergarten educator is the problem of the willingness of the place for 7 days, the commitment of the participants to follow up with training activities completed since leaving Office of the institution of the place of the participants work and family. 
As follo-up the activities Sidoarjo education service must maintain the basic tiered training kindergarten educators because can be used as a means for kindergarten educators who has not yet reached the standard of competence and qualifications set forth in legislation. Besides conducting training facilities need more note again as in the case of material handouts and materials to carry out spatial theory and practice material so that the participants are more comfortable. Discipline should be noted so that time according to the schedule has been set.

\section{REFERENCES}

[1] Charles, O. Jones. "Pengantar Kebijakan Publik. Jakarta: Raja Grafindo. 1996
[2] Sujiono, Yuliani Nuraini. Konsep Dasar Pendidikan Anak Usia Dini. Jakarta: Indeks. 2011.

[3] Wahab, Solichin Abdul. "Analisis Kebijasanaan: dari Formulasi ke Implementasi Kebijaksanaan Negara. Jakarta: Bumi Aksara. 1997.

[4] Dirjen PNFI. "Pertuara Menteri Pendidikan Nasional tentang Standar Pendidikan Anak Usia Dini, Jakarta: Dirjen PAUD. 2010.

[5] Permnediknas Nomor 16 Tahun 2007 tentang Standar Kualifikasi dan Kompetensi Guru.

[6] Permendiknas Nomor 58 Tahun 2009 tentang Standar Pendidikan Anak Usia Dini. 